\title{
ON RESEARCH 'WORTHY OF THE PRESENT'
}

\author{
IRIS VAN DER TUIN
}

Utrecht University

\begin{abstract}
How do we do our work as scholars in an age of electronic reason and computational media and under media-saturated, algorithmic conditions? In this article I suggest that the age of electronic reason, the ubiquity of computational media, and our condition as algorithmic are not only valid objects of study for humanists, digital humanists, and post-humanists today. As scholars, we are also and always/already affected by these so-called objects. We live and work with/in them, a situation that has methodological implications. By visiting concepts and arguments of thinkers like Rosi Braidotti, Donna Haraway, Achille Mbembe, and Isabelle Stengers, I ask: how not to be indifferent to knowing that algorithms repeat age-old patterns of in- and exclusion? How to act on possibilities for change as critical and creative researchers? How does research worthy of our time look?
\end{abstract}

Keywords: feminist theory new materialism, algorithmic condition, unkinning, making kin, subjectivity

${ }^{1}$ This title refers to Rosi Braidotti’s The Posthuman (2013, p. 52). 


\section{On Research 'Worthy of the Present'}

We live in an age of electronic reason and computational media (Mbembe, 2017). Our condition is algorithmic (Colman, Bühlmann, O’Donnell, \& Van der Tuin, 2018). How do we do our work as scholars in such an age and under such media-saturated conditions? What I am suggesting here is that the age of electronic reason, the ubiquity of computational media, and our condition as algorithmic are not only valid objects of study for humanists, digital humanists, and post-humanists today. As scholars, we are also and always/already affected by these so-called objects. We live and work with/in them, a situation that has methodological implications. In my work, I am trying to make these entanglements ${ }^{2}$ into the focal point of my research, which is to say that the research is not supposed to reflect on, i.e., distance itself from media, but that I am seeking to co-respond with them as this co-respondence ${ }^{3}$ is also and always/already happening. There is a fundamental duration ${ }^{4}$ or a non-linear temporality to today's research practice which is unavoidably our own onto-epistemology but also shared with others. Both co-respondence and the durational are, however, not to say that Difference as negatively balanced power and significatory practices has finally been exchanged for differing. ${ }^{5}$ After all, whereas we may dream of equality or a different, e.g., open, inclusive or horizontal difference, algorithms predict and shape the present and the future based upon past data. And past data are always contaminated with world historical imbalances structured around sexism, racism, colonialism, heteronormativity. ${ }^{6}$ But at the same time, "our computers execute in unforeseen ways, the future opens to the unexpected. Because of this, any programmed vision will always be inadequate, will always give way to another future” (Chun, 2011, p. 9). Or, also in the words of Wendy Chun, alongside the repetitive algorithmic effect of Difference, "new media's modes of repetition and transmission [...] open up gaps for a future beyond predictions based on the past” (Chun, 2011, p. 2). So, what are the methodological implications of all of this for the work contemporary scholars do? And how does research worthy of our time look? Let me start by reflecting on the choices that I have made as a scholar.

\section{Feminist and New Materialist Genealogies}

My research concerns primarily feminist and new materialist genealogies. There are at least two ways of dealing with genealogies: classification and cartography, both of which have featured prominently in my research thus far (Dolphijn \& Van der Tuin, 2012; Van der Tuin, 2015). What are the mechanisms through which open, inclusive or horizontal cartographies occur diffractively, i.e., by ways of surprise in hierarchically structured academic landscapes as

\footnotetext{
2 The etymology of 'implication' makes it a suitable word for the $21^{\text {st }}$ century: stemming from the early $15^{\text {th }}$ century, implication means an 'action of entangling' from Latin implicationem which means 'an interweaving, an entanglement' and from implicare which means to 'involve, entangle; embrace; connect closely, associate.'

Implication is therefore a folding-in.

${ }^{3}$ From Donna Haraway (2008) and Tim Ingold (2012).

4 This term grounds Henri Bergson's entire oeuvre.

${ }^{5}$ See for this term Rick Dolphijn and Iris van der Tuin (2012).

${ }^{6}$ See, for instance, the work of Cathy O’Neil (2016) and Safiya Umoja Noble (2018).
} 
feminist and new materialist cartographers become sensitized to "both the temporality of theory (virtual past and actualizations) and subjectivity (the new materialist placing of the scholarly subject; she is never fully fixed and therefore not in full control)” (Van der Tuin, 2014, p. 233)? ${ }^{7}$ The classificatory approach to knowledge production and epistemology employs spatially linear arrangements of knowledge, and theories pertaining to that knowledge, based upon the process of sequential negation. Classifications are built upon the dialectical assumptions that knowledge production and epistemology relate hierarchically, and that both knowledge and knowledge theory develop progressively. Even though these very basic assumptions have, since the 1970s, been repeatedly proven wrong by critical epistemologists, these disapprovals have not prevented feminist - and other — critical scholars from using the classificatory approach at the margins of academia (Van der Tuin, 2015). In contrast, the cartographical approach provides horizontal mappings of research. Knowledges, knowledge production, knowledge theories, and epistemology are no longer strictly distinguished from one another and additionally become multiplicitous. Cartographies are thus situated in the Harawayian sense and as "theoreticallybased and politically-informed reading[s] of the present” (Braidotti, 2002, p. 2). Continuing with the words of the Italy-born, Australia-raised, France-trained and Netherlands-based feminist philosopher Rosi Braidotti:

A cartographic approach fulfils the function of providing both exegetical tools and creative theoretical alternatives. [... Cartographies require] account[ing] for one's location in terms both of space (geo-political or ecological dimension) and time (historical and gene[a]logical dimension), and [...] provide alternative figurations or schemes of representation for these locations, in terms of power as restrictive (potestas) but also as empowering or affirmative (potentia) (Braidotti, 2002, p. 2).

The cartographical approach is one of the most important critical and creative responses to the neoliberal corporatization of academia. Additionally, this approach finds itself caught up in its own acceleration (exponentiality), as the embodied and embedded cartographer must immediately deal, not only with embodied and embedded images of knowing, but also with embrained, encultured, and encoded images (Collins, 1993, cited in Blackler, 1995); not only with embodied and embedded cognition, but also with enacted, affective, and extended cognition (Protevi, 2013).

In an attempt to acknowledge such complex and dynamic politics of location, ${ }^{8} \mathrm{I}$ have, in my recent research, begun to theorize how cartographies occur both "suddenly and seldom" (Van der Tuin, 2017) by way of posthuman interpellation (Van der Tuin, 2014). Accelerated embodiment and embeddedness can be said to act at the core of feminist, anti-racist, and queer identity politics in three fundamental ways: by operating on the interwoven levels of "differences between,” “differences amongst,” and “differences within” (Braidotti, 1994/2011); by

\footnotetext{
${ }^{7}$ The virtual and actual are Bergsonian notions referring to ways in which the present (e.g., known representations of gender and sexual relations) do not exhaust future or even past representations of what bodies can do. See Gilles Deleuze's Bergsonism from 1966 or recent writings of philosophers Elizabeth Grosz (2004, 2005) and Craig Lundy (2018) for introductions to these important notions.

8 This term is from Adrienne Rich (1986).
} 
demonstrating how critique has run out of steam (Latour, 2004); and by reaching out to Donna Haraway's call for a "sustaining [of] the possibility of webs of connections called solidarity in politics and shared conversations in epistemology” (1988, p. 584). Echoing Braidotti, Haraway’s plea in 'Situated Knowledges: The Science Question in Feminism and The Privilege of Partial Perspective' "for a doctrine and practice of objectivity that privileges contestation, deconstruction, passionate construction, webbed connections, and hope for transformation of systems of knowledge and ways of seeing” (Haraway, p. 584-5) acknowledges and embraces multiple webs: Firstly, “[w]ebs [that] have the property of being systematic, even of being centrally structured global systems with deep filaments and tenacious tendrils into time, space, and consciousness, which are the dimensions of world history” (Haraway, p. 588); secondly, webs of connections the answer of which to world historical oppression is not 'anything goes;' and finally, "the webs of differential positioning" about which critical and creative scholars are “insatiably curious” (Haraway, p. 590). This analysis of global systems that are, on the one hand, historically determined and frequently centrally structured, and the critical goal of webs of connections and creative curiosity about webs of differential positioning on the other, boils down to a certain practice of cartography. Systemic webs, however, (amongst other classifications) unsuccessfully try to fully apprehend and represent technobodies and their (knowledge) production. Differential ethico-onto-epistemological positionings are constantly being formed by those bodies from within both confining and potentially liberating webs. ${ }^{9}$ This process is one that occurs both consciously and unconsciously. ${ }^{10}$ In my own words:

[...] diffraction is always/already at work when one reads, writes and converses, in a scholarly manner and otherwise, [which] challenges the boundaries of a humanist interpretation of hailing. Subjectivity as it comes into being with/in diffraction follows from what [philosopher] Henri Bergson has called a 'disturb[ance of] my whole consciousness like a stone which falls into the water of a pond.' This stone generates a sudden interference pattern on the pond's surface. But the stone only apparently sets the still water into motion (does water-the physical H2O cycle-ever sit still?), which suggests that human consciousness must also be ever in motion. After all, [...] affected by [a] name-dropping, I [am] interrupted in a researcher-instrument-researched, pastpresent-future entanglement [...] (Van der Tuin, 2014, p. 242).

Both the workings of accelerated academia and the Janus face of situated map-making uncannily co-respond. That is, they correspond as well as emerge with the affordances of Web 3.0 — with the Internet of algorithmic media, automated document generation, and data subjectivity (Malabou, 2004/2008; Hoofd, 2012; Lievrouw, 2016). In my current research, I am interested in the confining and the potentially liberating implications of Web 3.0; in its conscious,

\footnotetext{
${ }^{9}$ Ethico-onto-epistemology comes from Karen Barad (2007).

10 This is a reference to N. Katherine Hayles’ How We Think, especially the argument that “[...] implicit in the concept of technogenesis, is to use digital media to intervene in the cycles of continuous reciprocal causality so that one is not simply passively responding to the pressures of accelerating information flow but using for different ends the very technologies applying this pressure” (Hayles, 2012, p. 102).
} 
unconscious, and nonconscious implications; ${ }^{11}$ in both Difference and in differing. How to go about this?

\section{A Common Genealogy?}

Cameroon-born and South Africa-based theorist Achille Mbembe writes in his groundbreaking Critique of Black Reason (2013/2017) that the world in the 21st century, as seen critically from the Black experience, is in need of the "mak[ing] possible [of] the emergence, relatively lucidly, of the new demands of a possible universalism” (p. 8). Both the capacity to formulate such demands (epistemology, methodology) and the objective of a universalist horizon itself (politics, ethics) are not without schisms, or without friction, or without historical and contemporary fiction. European schools of thought, enabled by and enabling violent practices of in- and exclusion, have intruded the Black experience's past and present; individually, structurally, and symbolically so; in both Africa and in the African diaspora alike (Europe inclusive). Reverberations of colonial and orientalist intrusions are ongoing and will have had foreseeable and unforeseeable effects in the future. European philosophies, situatedly desired and situatedly despised on more than one continent only, are both totalizing - they are a European reductionism, to use a concept from Martinican writer Aimé Césaire (1955/2000, p. 84) —and internally fractured along intersectional lines, the important foundation being a dialectic around issues of community. Mbembe (2013/2017) writes:

The call to race or the invocation of race, notably on the part of the oppressed, is the emblem of an essentially obscure, shadowy, and paradoxical desire - the desire for community. Such a desire is obscure, shadowy, and paradoxical because it is doubly inhabited by melancholia and mourning, and by a nostalgia for an archaic that which is always doomed to disappear. The desire is at once worry and anxiety-linked to the possibility of extinction - and a project. Moreover, it is the language of bemoaning and of a mourning that rebels in its own name (Mbembe, 2013/2017, p. 33).

Community seems to always have been a lure for both oppressor and oppressed. And we (we?) still yearn for a horizon on its register.

Mbembe's work is a standpoint theory 3.0 that complexifies American feminist epistemologist Sandra Harding's theory of strong objectivity (2013/2017). Instead of reaching beyond the Hegelian standpoint to a postmodernist epistemology, thus exchanging the desire for gendered, racialized, or sexualized community for a theory of difference as diversity, Mbembe reaches back into psychoanalysis as to understand the paradoxical communal dynamics of subject formation and ethical citizenship. I must exert myself to try to understand this paradoxicality, running the risk of European reductionism and of what Suriname-born Dutch feminist and anti-racist anthropologist Gloria Wekker (2016) calls-for the Dutch in particulara white innocence. Alongside such a striving for complication and worldliness on my part, as both a scholar and as a person, Mbembe's work on genealogy through and beyond European philosophical schools is all the more important for my research into feminist and new materialist

\footnotetext{
${ }^{11}$ Mark Hansen (2015) coined the term nonconscious.
} 
epistemology as I try to observe, make observable, and visualize and to contemplate and theorize sets of references and quotations that are generative and radically open, inclusive and horizontal. The project is to refrain from continuing the Eurocentric habit of closing-down one's speculations by reverse projection of European reductionism on politics of citation while at the same time doing justice to both histories and ongoing practices of scholarly European reductionism in intersectional keys. ${ }^{12}$

Leveling up standpoint theory implies working through community as recognizably dialectical and beyond a diversity thinking of adjectification. Mbembe at once affirms the Hegelian dialectics, just like French philosopher Simone de Beauvoir did for upper- and middleclass white women exclusively in The Second Sex (1949/2010), and he searches for a new horizon beyond totalization and without individualism. Working through a Hegelian dialectics of community, on the one hand, and, on the other, working beyond the individualist horizon of diversity thinking implies the necessity of both holding on to the ideal of community and of qualitatively shifting its foundational dialectics. For one thing, individualism - the common denominator of assuming One (Man) as well as of endless adjectification (Braidotti, 2006) must be avoided at all costs. Not only does individualism come dangerously close to advanced capitalist and neo-liberal normalizations but also does it impossibilize communal dynamic. For the carefully calibrated apparatus we must read the epilogue of Critique of Black Reason and turn to Mbembe's more recent monograph Politique de L'inimitié (2016). The epilogue suggests convincingly that the preferred apparatus implies a practice of unkinning (Mbembe, 2013/2017, p. 183). Unkinning (désapparentement) can best be explained with reference to the Bergsonian pair of virtual and actual (as opposed to the representationalist pair of possible and real). The main problem with community in most existing global, national and local circumstances-and these circumstances are entangled as well as they are more-than-human-is a discursive logic according to which we live and work as per "an approach that would aim first to enclose, to stay within the enclosure of what we call our own kin” (Mbembe, 2013/2017, p. 183). Such a logic realizes - in the sense of: it effectuates - the very possibility of difference as negation (Difference). In Mbembe’s words: "In such conditions we create borders, build walls and fences, divide, classify, and make hierarchies. We try to exclude - from humanity itself - those who have been degraded, those whom we look down on or whom do not look like us, those with whom we imagine never being able to get along” (Mbembe, 2013/2017, p. 182). Here we see the Foucauldian power/knowledge structures of how intersectional analytical categories such as race and coloniality are intimately bound up with lived experience as well as with knowledge production, and how daily life is in turn intimately bound up with academic study. ${ }^{13}$ How, then, to shift this European reductionism as it has been internalized within circumstances across the globe, across multiple scales, and across racial (and) colonial divides? Mbembe suggests starting not from the possibility of realizing what we think we know, but rather from a virtual space in

\footnotetext{
12 Grosz has stated insightfully that according to a representationalism, "[t]he possible [is] a reverse projection of the real" (Grosz, 2005, p. 107).

${ }^{13}$ For power/knowledge, see Michel Foucault, 1977/1980.
} 
which a durational apparatus actualizes different differences of which also surprising interference patterns instead of only recognizable vertical hierarchies in power and signification are part. He writes: "This question of universal community is therefore by definition posed in terms of how we inhabit the Open, how we care for the Open” (Mbembe, 2013/2017, p. 183). Inspired not by Bergson but rather by Martinican theorist Édouard Glissant's concept of ToutMonde or-in the striking translation of Mali-born and New York-based cultural theorist and filmmaker Manthia Diawara (2015) — worldmentality and by ancient African naturecultural cosmologies, Mbembe subscribes to "the very possibility of the construction of a common consciousness of the world” (Mbembe, 2013/2017, p. 182) as a posthumanism. This is not an individualism indeed.

Before I move on to discussing how Politique de L'inimitié elaborates on unkinning, I must turn to American feminist science studies scholar Donna Haraway’s (2016) seemingly opposite plea for making kin in her monograph Staying with the Trouble. How to make sense of the best of contemporary black theory advancing toward unkinning and the best of contemporary feminist theory advancing toward making kin instead? In fact, making kin argues also for a qualitative shifting of Foucauldian power/knowledge structures and its practice is equally posthumanist in spirit. Haraway writes: “My purpose is to make 'kin' mean something other/more than entities tied by ancestry or genealogy. [...] Kin making is making persons, not necessarily as individuals or as humans” (2016, p. 102-103). Interestingly, whereas Mbembe’s African cosmologies deal differently with ancestry and whereas genealogy has been reconfigured in Continental philosophy (Foucault, 1971/1977, Deleuze \& Guattari,1991/1994) as well as in black (Césaire, 1955/2000) and feminist theory (Van der Tuin, 2015), Haraway’s plea for a denaturalization and a posthumanization of kinship relations is precisely what Mbembe's complex take on community-to-come stands for as black people have more often than not been seen as nonpersons - and continuing - and given that we must move beyond both individual personhood and the totalizing humanism of Man. Haraway is explicit about these requirements when she writes: "Kinships exclude as well as include, and they should do that. Alliances must be attentive to that matter. [...] Making alliances requires recognizing specificities, priorities and urgencies. [...] Intending to make kin while not seeing both past and ongoing colonial and other policies for extermination and/or assimilation augurs for very dysfunctional 'families,' to say the least” (2016, p. 207, n. 12). Diffracting unkinning and making kin ultimately makes for an important interferential practice of epistemology/methodology and of politics/ethics.

Politique de L'inimitié, Mbembe's latest monograph, takes up the gauntlet of (explaining the necessity of) theorizing unkinning. Characterizing today's globalized world as enmitous and racism as informed by old and new nationalisms, Mbembe studies "what could be the foundations of a common genealogy and, hence, of a politics of life beyond humanism” (2016, p. 8; my translation). Mbembe argues, in a Fanonian key, for perpetual becoming (ontology) and for vulnerability as traversing enmity (politics, ethics), demanding reciprocity and caring relationality amidst the actualization of a renewed project of racial classification and differentiation, the biologico-genetic basis of which has in point of fact disappeared as a result of 
research in the technosciences of life, but-unfortunately — so has the difference between truth and fiction in the contemporary screenage (Mbembe, 2016, p. 161-162, 167-169). After having established, by taking the work of the Martinique-born psychiatrist and intellectual Frantz Fanon as exemplary, first, the being of both one Earth and of a multiplicity of places as a permanent replacement for Europe as the center of gravity of the world and, second, the need to responsibly dwell on Earth and cross borders, Mbembe writes in answer to Critique of Black Reason: "Then, in relative clarity, will emerge the demands, if not of a possible universalism, then at least of an idea of the Earth as that which is common to us, our common condition” (2016, p. 178; my translation). This emergence of the posthumanist demands of a transformed notion of universalism ${ }^{14}$ happens in a fragmented, earthly language "rooted in the paradoxes of body, flesh, skin and nerves” (Mbembe, 2016, p. 179; my translation). Historically and affectively embracing the body multiple, borrowing a term from Dutch medical anthropologist Annemarie Mol (2002), is the only way in which a situated knowledge as well as a new community can emerge (Mbembe, 2016, p.179). This is also how we may elaborate the necessary demands for the 21 st century.

Importantly, given the sociological, psychic and algorithmic workings of the racialized and racializing unconscious, contributing to and being part of a common genealogy in a posthumanist key is not easy to do for either white or black scholars, whether in the African diaspora or on the decentered European continent. Why? Because the following of Mbembe's questions from Politique de L'inimitié have the greatest relevance in relation to the actual doing of political and ethical genealogical work today:

But to say that [Europe] is no longer the center of gravity of the world, does that mean that the European archive is exhausted? Besides, has this archive truly been the product of a particular history only? Since the history of Europe has been confused for several centuries with the history of the world, and since the history of the world has been confused with that of Europe, does it not follow that this archive does not only belong to Europe? (Mbembe, 2016, p. 178; my translation)

Trying to see critically and creatively, i.e., intersectionally and interferentially ${ }^{15}$ from the European experience, we must start by way of situatedly affirming historical and affective multiplicity, which is one of the tasks that I have set myself in my feminist and new materialist research. How do we act on Mbembe's important insights and musings?

\footnotetext{
14 This notion is of course informed by Césaire’s complexification of the notion as the result of black consciousness raising: "[...] we asserted that our Negro heritage was worthy of respect, and that this heritage was not relegated to the past, that its values were values that could still make an important contribution to the world. [...] Universalizing, living values that had not been exhausted” (cited in Depestre, 1955/2000, p. 92). From Césaire (1955/2000, p. 52) also comes the notion of Negritude not as past- or as present-oriented, but rather that "[i]t is a new society that we must create" from the past and in the present, just like there is the need "to create a new language, one capable of communicating the African heritage. [...] an Antillean French, a black French that, while still being French, had a black character” (cited in Depestre, 1955/2000, p. 83). Indeed, “[w]e are not men for whom it is a question of 'either-or'”' (Césaire, 1955/2000, p. 51).

${ }^{15}$ For intersectionality and interference, see Geerts and Van der Tuin (2013).
} 


\section{On Not Being Indifferent}

In the year 2000, the Belgian philosopher of science Isabelle Stengers published the article ‘Another Look: Relearning to Laugh' in the most significant journal of feminist philosophy: Hypatia. The argument she presented was about ways of being a critical scientist and ways of critically reflecting on science. She asked whether feminists would have to abandon 'normal science' and embrace a woman's science. Her answer was a firm 'no.' After all, such a science of our own would leave us with the paradoxical situation of isolating ourselves ('another' science, objectivity, truth) on the one hand, while, on the other, putting normal science on a pedestal. Normal science would receive serious attention in the move away from it. Normal science comes into being when we argue against it. Perhaps normal science is more perverse than only being top-down, paradigmatic, control-driven? Stengers follows British philosopher and mathematician Alfred North Whitehead instead, who has suggested that philosophers of science study what scientists have to assume in order to make their claims. ${ }^{16}$ This methodology permits the critical philosopher of science to take all forms of scholarship seriously and to ask fundamental questions about their conditions of possibility. These are not the conditions of possibility that can be laid down in normative rules for scholarly research, but these are the situated conditions of possibility of virtual possibility. Questions asked are: how has this (mechanistic, narrative, empirical, philosophical, conceptual, ...) research been made possible? How did it come into being? What is affirmed here resembles what Haraway demonstrated in 'Situated Knowledges,' namely that even studies stirred by the God-trick lose their seemingly disembodied and disembedded status when we ask what they, too, had to assume. The technocratically mediated eye is not neutral. Decisions have been made that can be accompanied by other decisions, affected by mistakes, and be flawed.

The proposals of Haraway and Stengers should not be seen as relativist: Stengers affirms, and this is what I would like to borrow for the future of research in the 21st century, that it would be really "frighten[ing]” to be “on our way to the bureaucracy of 'objective' figures, 'rigorous' statistics, 'duplicable’ protocols indifferently defining rats, the 'youth,' or women as the objects of scientific knowledge” (Stengers, 2000, p. 43). What I like about this statement is twofold. First, special status is ascribed to “rats, the 'youth,' or women.” Animals, members of a certain generational cohort, and marginalized subjects — not only women but all beings affected by processes of perpetual pejorative Difference-remain firmly positioned as the objects of our research. Second, these objects should not be "indifferently defin[ed]" following a bureaucratic procedure. The seeming objects of our research become firmly positioned as agential subjects. This has exactly been Mbembe's move in both Critique of Black Reason and in Politique de $L$ 'inimitié. Taking the two aforementioned aspects together: research in the 21st century must continue to embrace a power/knowledge that would lead to choosing as research topics those nodal points in our society and cultural production that have something to do with in- and exclusion, but we must also make sure to work from a theory about how these inequalities and

\footnotetext{
${ }^{16}$ See for this take on Whitehead: Stengers (2002/2011, p. 79).
} 
possible universalisms may feed back into the work we do at the university. We must not work indifferently, because we want to make a difference with our work. We need the space and the time for fundamental research in this era of vehement bureaucratization of research, especially in the turn to externally funded research. Take Stengers' example of 'youth.' The youth is a strategic research area at many universities and in many (trans)national research funding schemas, but we all know that generations are nothing but actualizations of the more fundamentally dynamic processes of growing up, of zigzagging movement in thinking and doing. Does funded research manage to reach this movement? Can we base our conclusions in datasets? What counts as data? Is a datum a statistical generalization or should we also look at individual cases in the data set and beyond ${ }^{17}$ These kinds of questions are my preferred questions. Taking questions about the conditions of possibility of virtually possible research on board allows us to also affirm the many different approaches we choose for our scholarship into power/knowledge and into un/kinning. From the huge statistical projects of the digital humanities that keep on getting funding to the baby steps we are making in the direction of trying to understand what digital humanities can actually do. From the hermeneutical textual studies that humanities scholars keep on refining up until devising projects that explicitly traverse the two cultures of British scientist and writer C. P. Snow ${ }^{18}$ by developing the affective turn, the material turn, the computational turn. The humanities are methodologically versatile, well versed epistemologically and contribute to issues of societal concern... by posing the right questions. In that sense I would also wish for questions about the foundations of the human sciences. There is an age-old tradition of studying the history and philosophy of the natural sciences. I plead for us to take on board questions of history and philosophy of the human sciences. In his Keywords: A Vocabulary of Culture and Society, the Welsh cultural theorist Raymond Williams (1976/1983, p. 219) defined nature as "perhaps the most complex word in the language." But if we look at his definition of 'culture,' it “is [too] one of the two or three most complicated words in the English language” (Williams, [1976] 1983, p, 87). It is 'naturecultures' that comes out of such studies. ${ }^{19}$ Is there a need to draw the line?

\footnotetext{
${ }^{17}$ Ezekiel J. Dixon-Roman’s Inheriting Possibility: Social Reproduction and Quantification in Education (2017) answers these questions by seeking alliances with the work of Vicki Kirby (2011).

18 See Snow (1959/1965).

19 'Naturecultures' is a term from Haraway (2003).
} 


\section{References}

Barad, K. (2007). Meeting the universe halfway: Quantum physics and the entanglement of matter and meaning. Durham, NC: Duke University Press.

Beauvoir, S. (2010). The second sex. (C. Borde \& S. Malovany-Chevallier, Trans.). New York: Alfred A. Knopf. (Original work published 1949).

Blackler, F. (1995). Knowledge, knowledge work and organizations: An overview and interpretation. Organization Studies, 16(6), 1021-1046.

Braidotti, R. (2002). Metamorphoses: Towards a materialist theory of becoming. CambridgeMalden: Polity.

Braidotti, R. (2006). Transpositions: On nomadic ethics. Cambridge - Malden: Polity.

Braidotti, R. (2011). Nomadic subjects: Embodiment and sexual difference in contemporary feminist theory ( $2^{\text {nd }}$ ed.). New York: Columbia University Press. (Original work published 1994).

Braidotti, R. (2013). The posthuman. Cambridge - Malden: Polity Press.

Césaire, A. (2000). Discourse on colonialism; (J. Pinkham, Trans.). New York, NY: Monthly Review Press. (Original work published 1955).

Chun, W. (2011). Programmed visions: Software and memory. Cambridge, MA: MIT Press.

Colman, F., Bühlmann, V., O’Donnell, A., \& Van der Tuin, I. (2018). Ethics of coding: A report on the algorithmic condition [EoC]. H2020-EU.2.1.1. - INDUSTRIAL LEADERSHIP Leadership in enabling and industrial technologies - Information and Communication Technologies. Brussels: European Commission.

Deleuze, G. \& Guattari, F. (1994). What is philosophy?, (H. Tomlinson \& G. Burchell, Trans.). New York: Columbia University Press. (Original work published 1991).

Deleuze, G. (1991). Bergsonism, (H. Tomlinson \& B. Habberjam, Trans.). New York: Zone Books. (Original work published 1966).

Depestre, R. (2000) An interview with Aimé Césaire. In A. Césaire. Discourse on colonialism (pp. 79-94). (J. Pinkham, Trans.). New York, NY: Monthly Review Press. (Original work published 1955).

Diawara, M. (2015) Édouard Glissant's worldmentality: An introduction to one world in relation. South as a State of Mind, 6. Retrieved from

https://www.documenta14.de/en/south/34_edouard_glissant_s_worldmentality_an_introd uction_to_one_world_in_relation

Dixon-Roman, E. (2017). Inheriting possibility: Social Reproduction and quantification in education. Minneapolis, MN: University of Minnesota Press.

Dolphijn, R. \& Van der Tuin, I. (2012). New materialism: Interviews \& cartographies. Ann Arbor: Open Humanities Press.

Foucault, M. (1977). Nietzsche, genealogy, history. In D. Bouchard (Ed.) Language, countermemory, practice: selected essays and interviews (pp. 139-164). Ithaca, NY: Cornell University Press. (Original work published 1971). 
Foucault, M. (1980). Power/knowledge: Selected interviews and other writings, 1972-1977. (C. Gordon, Trans). Brighton, Harvester Press. (Original work published 1977).

Geerts, E. (2013). From intersectionality to interference: feminist onto-epistemological reflections on the politics of representation. Women's Studies International Forum, 41(3), 171-178.

Grosz, E. (2004). The nick of time: Politics, evolution, and the untimely. Durham, NC: Duke University Press.

Grosz, E. (2005). Time travels: Feminism, nature, power. Durham, NC: Duke University Press. Hansen, M. (2015). Feed-forward: On the future of twenty-first century media. Chicago, IL: University of Chicago Press.

Haraway, D. (1988). Situated knowledges: The science question in feminism and the privilege of partial perspective. Feminist Studies, 14(3), 575-599.

Haraway, D. (2003). The companion species manifesto: Dogs, people, and significant otherness. Chicago, IL: Prickly Paradigm Press.

Haraway, D. (2016). Staying with the trouble: Making kin in the Chthulucene. Durham, NC: Duke University Press.

Harding, S. (1993). Rethinking standpoint epistemology: What is 'strong objectivity'? In L. Alcoff \& E. Potter (Eds.) Feminist Epistemologies (pp. 48-82). New York, NY: Routledge.

Hayles, N. (2012). How we think: Digital media and contemporary technogenesis. Chicago, IL: The University of Chicago Press.

Ingold, T. (2012) Toward an Ecology of Materials. Annual Review of Anthropology, 41, 427-42. Kirby, V. (2011). Quantum anthropologies: Life at large. Durham, NC: Duke University Press.

Latour, B. (2004). Why has critique run out of steam? From matters of fact to matters of concern. Critical Inquiry, 30, 225-48.

Lundy, C. (2018). Deleuze's Bergsonism. Edinburgh: Edinburgh University Press.

Mbembe, A. (2016). Politique de l'inimitié. Paris: La. Découverte.

Mbembe, A. (2017). Critique of black reason. (L. Dubois, Trans.). Durham, NC: Durham University Press. (Original work published 2013).

Mol, A. (2002). The body multiple: Ontology in medical practice. Durham, NC: Duke University Press.

Noble, S. (2018). Algorithms of oppression: How search engines reinforce racism. New York, NY: NYU Press.

O’Neil, C. (2016). Weapons of math destruction: How big data increases inequality and threatens democracy. New York, NY: Crown.

Protevi, J. (2013). Life, war, Earth: Deleuze and the sciences. Minneapolis, MN: University of Minnesota Press.

Rich, A. (1986). Notes toward a politics of location. In Blood, Bread and Poetry: Selected Prose 1979-1985 (pp. 210-232). London: W.W. Norton. 
Snow, C. (1965). The two cultures: and a second look. London: Cambridge University Press. (Original work published 1959).

Stengers, I. (2000). Another look: Relearning to laugh. Hypatia: A Journal of Feminist Philosophy, 15(4), 41-54.

Stengers, I. (2011). Thinking with whitehead: A free and wild creation of concepts. Cambridge, MA: Harvard University Press. (Original work published 2002).

Van der Tuin, I. (2014). Diffraction as a methodology for feminist onto-epistemology: On encountering Chantal Chawaf and posthuman interpellation. Parallax, 20(3), 231-244.

Van der Tuin, I. (2015). Generational feminism: New materialist introduction to a generative approach. Lanham - Boulder: Lexington Books.

Van der Tuin, I. (2017) Signals falling: Reading Woolf and Guattari diffractively for a new materialist epistemology. The Minnesota Review: A Journal of Creative and Critical Writing, 88(1), 112-115.

Wekker, G. (2016). White innocence: Paradoxes of colonialism and race. Durham: Duke University Press.

Williams, R. (1983). Keywords: A vocabulary of culture and society. New York: Oxford University Press. (Original work published 1976). 